\title{
Russian Maritime Education Should Be! What to Be?
}

\author{
Sofya Stukanova ${ }^{1},{ }^{*}$ Irina Stukanova ${ }^{1}$, Alexander Agafonov ${ }^{2}$ \\ ${ }^{1}$ Moscow Polytechnic University, Moscow, Russia \\ ${ }^{2}$ Cheboksary Institute (Branch) of Moscow Polytechnic University, Cheboksary, Russia \\ *Email: stukanova_ss@mail.ru
}

\begin{abstract}
The growth of the national economy and the development of the quality of human resources are in a constant and continuous relationship. Professional maritime education as a component of the socio-economic system that forms human capital requires implementing new approaches; relevant educational programs are developed considering industries' level and development directions. Strategically important maritime and shipbuilding industries today have several problems caused by the need to strengthen the professional training of specialists and the formation of supraprofessional competencies. The purpose of the work is to study the current state and determine the prospects for the development of maritime education, which provides the domestic labour market with specialists and officers of marine and shipbuilding profiles. The subject of the study is the motivational and educational-professional components of the quality of human resources of marine specialists. The article, based on a modern theoretical and methodological basis, examines the evolution and expected results of the choice of profession of specialists in marine and shipbuilding profiles, the state and needs of the labour market of the marine industry and concludes the need and relevance of the formation of students not only professional but also supra-professional competencies.
\end{abstract}

Keywords: Quality of education, Professional education, Problems of training marine specialists, Professional and supra-professional competencies.

\section{INTRODUCTION}

The opportunities, directions and sustainability of the development of the national economy are primarily determined by the availability and development level of the quality of human resources and human capital, in the formation of which a set of institutional and individual stakeholders is involved, directly or indirectly, to a greater or lesser extent influencing the effectiveness of the process under consideration.

The vocational education system and, in particular, maritime education is of decisive importance in forming qualitative characteristics of human resources. However, the ongoing changes in technological, socio-economic, and other spheres necessitate the introduction of transformational processes and new approaches to training as such and, first of all, to the content and orientation of educational programs for training marine specialists.
The noted necessity is explained by the importance of developing both the military and merchant marine. The President of Russia, V.V. Putin, emphasising that "a strong Russia $\langle\ldots\rangle$ needs a powerful, balanced navy", noted the strategic importance of the former in current conditions. [1]. The role of the development of the second one is conditioned by the growth of the global sea transportation market, on the one hand, the possibilities of the marine and shipbuilding sectors of the economy to act as drivers of system modernisation [2], on the other.

Thus, according to the results of research by Clarkson Research Services, in 2021, sea transportation in the world will reach 12 billion tons, showing an increase of $4.2 \%$, exceeding the indicators of 2019 and levelling the fall of 2020 [3]. As for Russia, the indicators characterising the activity of the domestic merchant fleet, according to the Institute for Integrated Studies of the National Maritime Policy of MIREA-RTU, are not too optimistic (Table 1). Moreover, we should agree 
Table 1. Individual characteristics of the state of the Russian merchant fleet, 2020 [4]

\begin{tabular}{|l|c|c|}
\hline \multicolumn{1}{|c|}{ Characteristic } & $\begin{array}{c}\text { Ships of the Navy flying the flag } \\
\text { of the Russian Federation }\end{array}$ & $\begin{array}{r}\text { Ships of the navy } \\
\text { belonging to Russian } \\
\text { shipowners, but sailing under } \\
\text { foreign flags }\end{array}$ \\
\hline The total number of ships, units. & 1176 & 247 \\
\hline The total deadweight of ships, million tons. & 7.969 & 14.7 \\
\hline The average age of the fleet, years & 20.7 & 12.9 \\
\hline $\begin{array}{l}\text { Russian fleet share in global cargo } \\
\text { transportation, \% }\end{array}$ & & \multicolumn{2}{|c|}{0.1} \\
\hline
\end{tabular}

with the opinion of A. Balyberdin that such a severe problem as increasing the competitiveness of the Russian fleet requires a serious approach to its solution [4].

Of course, this problem has a complex character; however, the human factor plays a key role in its solution, the presence of not only professional but also supra-professional competencies among specialists in marine and shipbuilding areas that meet the needs of the time, provide a basis for the development of innovative motivation [5] and the qualitative development of the marine and shipbuilding sectors of the economy. In this regard, we consider it necessary to consider the most significant components of modern maritime education, as well as the main methodological approaches to the development of educational programs and training of marine specialists and methods of attracting them to the profession, which together with their application will allow considering the interests of not only future industry workers but also other related and external stakeholders.

\section{RESEARCH METHODOLOGY}

Methodological aspects of the functioning of the educational environment, factors and results of its influence on the development of the quality of human resources, principles of interaction with various institutions and socio-economic systems at all levels are developed by many branches of scientific knowledge. However, the multilevel and complexity of the educational environment, the need to consider diverse components, and the variable nature of determinism that determines the educational process results make it completely justified in such studies to rely on an interdisciplinary approach. Modern scientists agree that science needs a methodological basis for interdisciplinary research [6;7], in particular because they allow overcoming certain limitations inherent in certain special methods.
Moreover, the integration processes actively taking place in the modern economy and society, the complexity of the objects of research, as well as the problems of this work determine the possibility and expediency of applying an ecosystem approach when considering the triad "student/cadet - university - labour market/employer" as a new actor of the economy and a unit of economic analysis in which the noted economic agents of the triad are "embedded" in a network of interrelated relationships.

The present work is based on the application of conceptual and methodological approaches of philosophy and sociology of education, the economics of education and labour economics, theory of systems, methods of comparison and critical analysis, citation and review, which allows to form and substantiate the theoretical and methodological basis of the study. The reliability of the conclusions and conclusions presented in work is based on the use of the laws of formal logic (in particular, the law of sufficient reason) and is confirmed by the results of quantitative and qualitative studies presented by data from Russian and international statistical databases, research centres, peer-reviewed scientific publications.

\section{ENTRANT - STUDENT/CADET - EMPLOYEE/OFFICER: EVOLUTION OF MOTIVES AND EXPECTED RESULTS}

In the ecosystem under study, motivation to choose a future profession and motivation to study play a crucial role in shaping the quality of education and training of highly qualified specialists.

The analysis of the number of first-year students of maritime universities, on the one hand, is characterised by positive dynamics. On the other hand, the results of the admission campaign-2021 showed an increase in the interest of applicants in specialities related to IT technologies [8], while the demand for training in economic and legal specialities remains traditionally 
high even in maritime industry educational organisations.

The needs of the country's economy for specialists in marine and shipbuilding profiles determine the availability of a sufficiently large number of budget places for the relevant areas and specialities of training. However, the competition for these specialities is low relative to the marked educational programs, and the average score of applicants is $40-55$ points lower (Table 2).

It is gratifying that among the motives for choosing a profession among future specialists of the marine and shipbuilding complexes and, in particular, among cadets of military universities, internal, individually, and socially significant motives have been prevailing for a long time $[2,10,11]$. However, as the results of other studies show, the motives for choosing a profession and career among students and cadets for older courses are changing. Thus, the leading positions in the hierarchy of motives begin to be occupied by the desire for material prosperity, self-development, promotion and performance of certain activities [12].

The dynamism of the motives of professional activity is natural, but an acute shortage of personnel at sea and in the shipbuilding industry has been observed for more than one year, which confirms the gap between the professional expectations and realities of students/ cadets and specialists and officers who have started the professional activity.

Table 2. Results of admission to the main budget places for bachelor's degree programs at St.

Petersburg State Maritime Technical University (within the admission control figures minus the special quota and the quota for admission to targeted training) [9]

\begin{tabular}{|c|c|c|}
\hline Name of the speciality & 2021 & 2019 \\
\hline $\begin{array}{l}\text { 10.03.01 - Information security: } \\
\text { enrolled, people } \\
\text { competition, person/place } \\
\text { average score }\end{array}$ & $\begin{array}{c}33 \\
29.4 \\
239.1 \\
\end{array}$ & $\begin{array}{c}25 \\
16.1 \\
208.2\end{array}$ \\
\hline $\begin{array}{l}\text { 38.03.01 - Economy: } \\
\text { enrolled, people } \\
\text { competition, person/place } \\
\text { average score }\end{array}$ & $\begin{array}{c}15 \\
38.5 \\
260.1\end{array}$ & $\begin{array}{c}15 \\
45.1 \\
244.5\end{array}$ \\
\hline $\begin{array}{l}\text { 38.03.02 - Management: } \\
\text { enrolled, people } \\
\text { competition, person/place } \\
\text { average score }\end{array}$ & $\begin{array}{c}10 \\
54.6 \\
259.7\end{array}$ & $\begin{array}{c}10 \\
59.7 \\
238.1\end{array}$ \\
\hline $\begin{array}{l}\text { 40.03.01 - Law: } \\
\text { enrolled, people } \\
\text { competition, person/place } \\
\text { average score }\end{array}$ & $\begin{array}{c}4 \\
77,0 \\
262.7\end{array}$ & $\begin{array}{c}17.0 \\
23.2 \\
253.1\end{array}$ \\
\hline $\begin{array}{l}26.03 .02 \text { - Shipbuilding, ocean engineering and system } \\
\text { engineering of marine infrastructure facilities: } \\
\text { enrolled, people } \\
\text { competition, person/place } \\
\text { average score }\end{array}$ & $\begin{array}{c}202 \\
4.3 \\
207.5\end{array}$ & $\begin{array}{c}240 \\
5.0 \\
192.5\end{array}$ \\
\hline $\begin{array}{l}26.05 .02 \text { - Design, study and repair of power plants and } \\
\text { automation systems of ships and vessels: } \\
\text { enrolled, people } \\
\text { competition, person/place } \\
\text { average score }\end{array}$ & $\begin{array}{c}95 \\
5.3 \\
212.4\end{array}$ & $\begin{array}{c}82 \\
7.8 \\
190.8\end{array}$ \\
\hline
\end{tabular}




\section{LABOUR MARKET: CURRENT STATE AND CAUSES OF IMBALANCES}

The current characteristics of the labour market in the marine and shipbuilding industries reflect the discrepancy between the supply and demand of labour. Moreover, in some areas, this discrepancy is primarily national, and in others, it is global (although the latter also takes place at the national level, to a certain extent, it reduces the tension of the international market, thus increasing the shortage of personnel in Russia).

Thus, as a result of comparing supply and demand in the labour market of shipbuilding professions, in the first half of 2021, the number of vacancies in the industry in question increased by $128 \%$ compared to the same period in 2020. A study of the causes of the current problem in the labour market revealed that only in St. Petersburg $63 \%$ of employees of the shipbuilding industry are thinking about changing their profession, more than $40 \%$ of whom are not satisfied with their salary level [13].

The problem of the shortage of officers in the merchant fleet is global. According to experts, by the end of this year, the shortage of personnel may reach 26.240 people. Moreover, according to forecast estimates, in the next 5 years, the demand for officers of the shipping industry will increase to 89.510 people [14]. In particular, in connection with the above, the International Chamber of Shipping also stated the need to make active efforts to develop maritime education and promote personnel retention in every possible way.

These problems are also characteristic of domestic reality since, as noted by the Russian Seafarers' Union, there has been a decrease in the number of officers in our country for several years [15]. The situation is also complicated because a significant part of the most trained maritime university graduates works in foreign companies and countries. It is increasingly noted that "the merchant fleet lacks personnel, and sailors lack knowledge and desire to work in Russia" [16].

One of the reasons for the current situation is traditionally called uncompetitive wages, but also more and more often among the reasons for the imbalances in the labour market, opinions about the declining level of training of cadets and the downward trend in the quality of maritime education are heard more and more actively [5].

We can agree with this opinion regarding the influence of several objective reasons on the training of cadets. Firstly, to train a high-level professional, it is necessary to rely on a proper school base, which is often insufficient. Secondly, the international standards for the training of seafarers (International STCW Convention), based on the European approach to the definition of competencies (as a minimum to be achieved), turned out to be significantly lower than Soviet standards. And, thirdly, it is necessary to note the insufficient amount of practice during the training of cadets, the decreasing number of practising teachers, the international exchange of experience in the implementation of educational programs and the formation, in addition to professional, supraprofessional competencies of students.

\section{CONCLUSION}

Despite the existing problems, the Russian navy and the shipbuilding industry have the potential for development. The ecosystem approach to the implementation of marine education makes it possible to activate the participation of the entire marine community in the preparation of high-quality personnel. However, the leading role in this issue, of course, belongs to domestic maritime universities, which, in our opinion, should conduct parallel work in two fundamental and complementary areas: the professional training of marine specialists and the formation of their supra-professional competencies.

As for the first direction, today, all higher educational institutions apply a competency-based approach to training, considering the requirements of international conventions, which reflect the requirements and standards of training of all crew members. However, to increase the competitiveness of Russian maritime specialists and the quality of their professional training, it is advisable, in our opinion, to introduce "advanced quality" training, in which Russian training standards will be higher than international ones, especially since our education system has, in this case, a very successful Soviet experience.

The training of high-class specialists will help to level out the existing imbalances in the labour market. But to stabilise this market, it is crucial not only to "inject" new personnel into the industry but also to retain employees in the profession. The gap in the expectations of students and the reality that specialists face when starting work negatively affects motivation and loyalty to the profession. In this regard, it is vital to form future marine specialists with poly profile knowledge and competencies, including a set of competencies of specialists of different professions that make up one professional field.

Regarding the implementation of the second direction, we consider it necessary to introduce more widely into educational programs blocks and tools for the development of students' non-technical skills. Based on the research results, we believe that it is essential for employers to motivate marine specialists to stay in the profession and possess such supra-professional skills and competencies as leadership, emotional intelligence, 
stress tolerance, and decision-making, sociability, adaptability, innovation, etc.

The corresponding tools are being actively developed today. In cooperation with the created on the Initiative of the President V.V. Putin ANO "Russia - a land of opportunities", universal diagnostic materials are increasingly being used to assess the level of formation of students' supra-professional competencies that are so relevant today, and competence centres that open in educational institutions help students form individual professional development trajectories, considering the motives and needs of future specialists.

Close interaction with employers, considering the requirements and changes in the labour market, allow such centres to become a point of attraction for students and provide them with equal opportunities for professional, personal and social development.

Improving the quality of human capital, opportunities for the formation of multi-professional and supra-professional competencies are also important for cadets and students of maritime and shipbuilding universities, since a more targeted professional training, an individual approach to the development of career maps, the formation of the necessary leadership, communication, managerial, social and civil competencies will strengthen the prestige of Russian maritime education, increase the attractiveness of the profession and loyalty to it among graduates and specialists.

\section{REFERENCES}

[1] Putin said that a strong Russia needs a powerful Navy [Putin zayavil, chto sil'noj Rossii nuzhen moshchnyj Voenno-morskoj flot]. Retrieved from: https://tass.ru/armiya-i-opk/12198599

[2] S.S. Stukanova, I.P. Stukanova, A.V. Agafonov, Qualitative characteristics of the educational environment for training personnel of marine and shipbuilding professions [Kachestvennye harakteristiki obrazovatel'noj sredy podgotovki kadrov morskih i sudostroitel'nyh professij], Marine intelligent technologies [Morskie intellektual'nye tekhnologii] 1-1(51)b (2021) 9097. DOI: https://doi.org/10.37220/MIT.2021.51.1.013

[3] The volume of the Russian sea transportation market will exceed the 2019 level in 2021 [Ob"emy rynka rossijskih morskih perevozok prevysyat v 2021 godu uroven' 2019-go]. Retrieved from: $\quad$ https://www.rzd-partner.ru/watetransport/news/obemy-rynka-morskikh-perevozokprevysyat-v-2021-godu-uroven-2019-goda-/
[4] A. Balyberdin, Russian cargo - under the Russian flag, Is everything so unambiguous? [Rossijskij gruzy - pod rossijskij flag, Tak li vse odnoznachno?], Sea news of Russia [Morskie vesti Rossii]. Retrieved from: http://www.morvesti.ru/analitika/1692/85436/

[5] O.I. Menshikova, S.S. Stukanova, I.P. Stukanova, Innovative Motivation as a Factor of Improving the Quality of Human Resources and the Development of Socio-economic Systems, in: Bogoviz A. (eds) Complex Systems: Innovation and Sustainability in the Digital Age, Studies in Systems, Decision and Control, Springer, Cham 282 (2020) 11-18. DOI: https://doi.org/10.1007/978-3-030-44703-8 2

[6] M. MacLeod., N.J. Nersessian, Interdisciplinary Problem-Solving: Emerging Models of Integrative System Biology, European Journal for Philosophy of Science 6 (2016) 401-416. DOI: https://doi.org/10.1007/s13194-016-0157-x

[7] S.S. Stukanova, I.P. Stukanova, A.V. Agafonov, I.A. Murog, Philosophical and Methodological Aspects of Labour Quality Management in the Era of Intelligent Machines. In: Popkova E., Sergi B. (Eds.) Economic Issues of Social Entrepreneurship. Palgrave Macmillan, 2021, pp. 445-455. DOI: https://doi.org/10.1007/978-3-030-77291-8_41

[8] Universities note an increase in the number of applicants [Vuzy otmechayut rost chisla abiturientov]. Retrieved from: https://ria.ru/20210802/abiturienty1743915910.html

[9] The results of the admission of previous years. St. Petersburg State Maritime Technical University [Rezul'taty priema proshlyh let, SanktPeterburgskij gosudarstvennyj morskoj tekhnicheskij universitet]. Retrieved from: https://www.smtu.ru/ru/page/512/

[10] L.A. Zolotovskaya, Features of the professional formation of cadets in the process of studying at a military university, Proceedings of the First International Scientific and Practical Symposium "Interdisciplinary research in Science and education: Psychological Sciences" [Osobennosti professional'nogo stanovleniya kursantov v processe obucheniya v voennom vuze, Sbornik trudov Pervogo Mezhdunarodnogo nauchnoprakticheskogo symposiums "Mezhdisciplinarnye issledovaniya $\mathrm{v}$ nauke i obrazovanii: Psihologicheskie nauki"], 2012, ss. 27-36b MANU, Kyiv.

[11] V.I. Kholodov, Military education in the representations of cadets of higher military 
educational institutions [Voennoe obrazovanie $\mathrm{v}$ predstavleniyah kursantov vysshih voennyh uchebnyh zavedenij], News of higher educational institutions, Volga region, Humanities [Izvestiya vysshih uchebnyh zavedenij, Povolzhskij region, Gumanitarnye nauki] 4(12) (2012) 180-188.

[12] A.V. Fomin, Typology of cadets of military universities: motivational cross-section [Tipologiya kursantov voennyh vuzov: motivacionnyj srez], Modern problems of science and education [Sovremennye problemy nauki i obrazovaniya] 2 (2015) 641-652.

[13] E. Dubinkin, Shipbuilding lacks qualified personnel [Sudostroeniyu ne hvataet kvalificirovannyh kadrov]. Retrieved from: https://vedomostispb.ru/economics/articles/2021/09/30/889149peterburgskie-sudostroiteli-nedovolni-zarplatoiusloviyami-truda

[14] The navy is sorely lacking officers, but there are more women sailors [Flotu katastroficheski ne hvataet oficerov, zato zhenshchin-moryakov stalo bol'she]. Retrieved from: https://logirus.ru/news/transport/flotu_katastrofiche ski_ne khvataet_ofitserov-_zato zhenshchinmoryakov_stalo_bolshe.html

[15] The problem of shortage of naval personnel may get out of control [Problema nekhvatki morskih kadrov mozhet vyjti iz-pod kontrolya]. Retrieved from: https://portnews.ru/digest/22574/

[16] Ya. Maltseva, The Merchant Fleet lacks personnel, and sailors lack the knowledge and desire to work in Russia [Torgovomu flotu ne hvataet kadrov, a moryakam - znanij i zhelaniya rabotat' v Rossii]. Retrieved from: https://www.newsvl.ru/economics/2021/10/26/203 $\underline{775 /}$ 